\title{
Determination of Different Chemical Constituents of Fruit, Leaves and Oil of Olea cuspidata (Wild Olive) Grown at Rawalakot, Azad Jammu and Kashmir
}

\author{
Rabab Rafaqat ${ }^{1}$, Habib Ahmed Rathore ${ }^{1}$, Tariq Masud ${ }^{2}$, Imran Hayat ${ }^{1 *}$ and Imtiaz Hussain ${ }^{1}$
}

${ }^{1}$ Department of Food Science and Technology, University of the Poonch, Rawalakot, Azad Kashmir; ${ }^{2}$ PMAS University of Arid Agriculture, Rawalpindi, Pakistan.

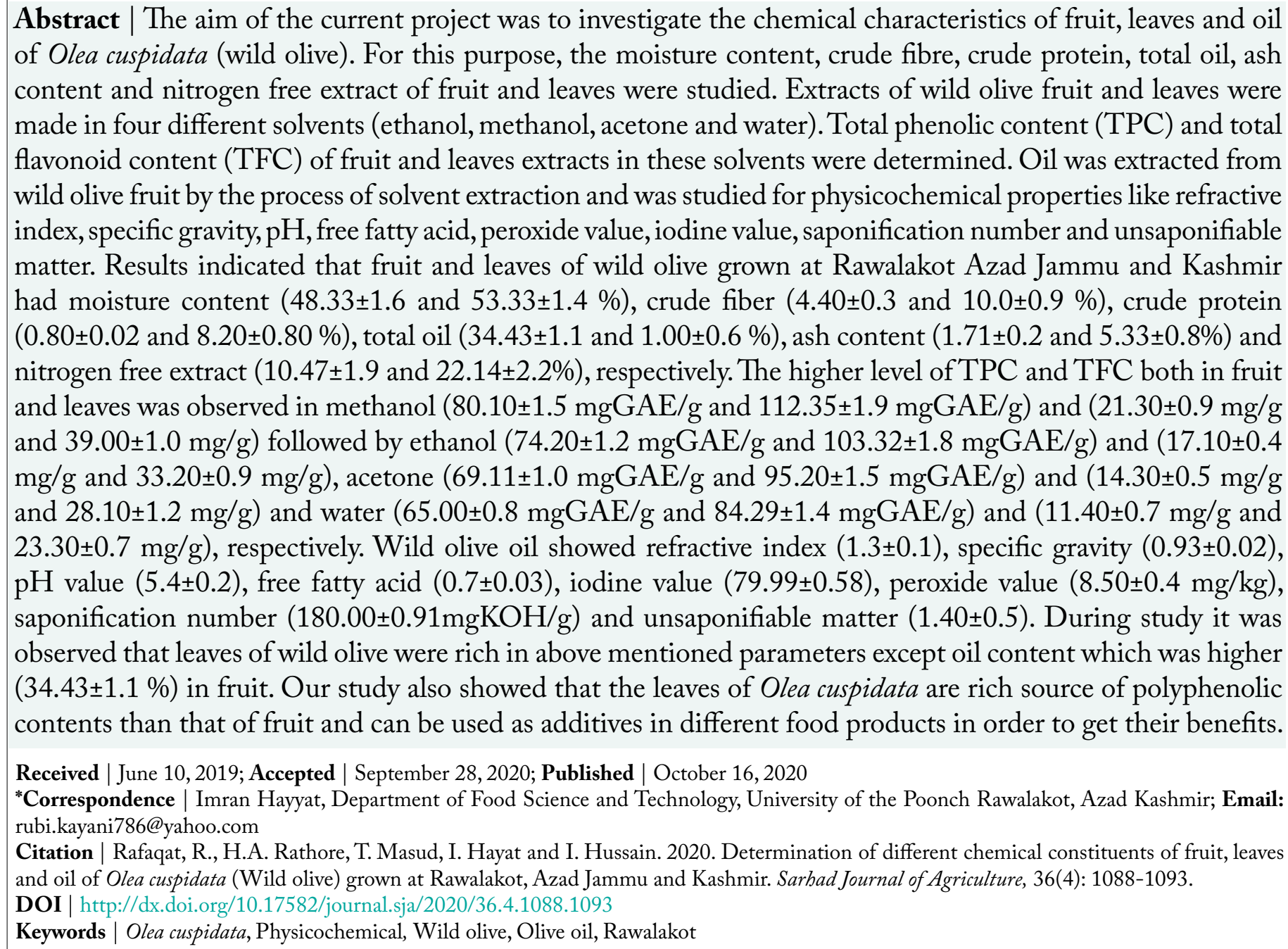

\section{Introduction}

$O$ ea europea, a cultivated tree of olive that is related to the family oleacea, having thirty genera and about six hundred species is a rich source of olive oil and is grown throughout Mediterranean, Europe, Africa, Iran and Asia (Besnard et al., 2002; Hegazi et al., 2016). The genus Olea is derived from two words, 
the Greek word "elaia" and the Latin word "oleum" (Hashmi et al., 2015). Among different cooking oils, olive oil has a unique nature because it contains very high amount of fatty acids (unsaturated) (Olivaria et al., 2005). Level of oleic acid is very high (80 \%) in olive oil which puts it at the topmost place of monounsaturated fat (Karleskind and Wolf, 1998; Murkovic et al., 2004). Higher intake of olive oil in diet is linked with low threat of demise from all reasons (Sala Vila et al., 2016). The olive stone produce oil with very good quality which can be used for the preparation of additives or medicinal components (Hannachi et al., 2013). Along with the importance of olive oil, its parts like fruit and leaves have a significant history of nutraceutical value due to the presence of important phenolic compounds (Soni et al., 2006).

Besides cultivated olive, there is wild species of olive called Olea cuspidata which is very common in Azad Kashmir and also widely spread in hilly areas of Pakistan, India, Iran, China, Saudi Arabia, Nepal and Southeast Africa (Bartolini et al., 2002; Ganino et al., 2006). Length of the tree is $10-50 \mathrm{ft}$. with grey to brown bark on stem which is normally very smooth in texture on younger trees but rough and deeply fissured on older trees (Ivan, 2005). Farmers in these areas use fruit of wild olive to make their animals fat (Nisar et al., 2002). A few of the scientists have reported that wild olive may be used as a source of antioxidants and have ability to hinder the growth of certain microorganisms because of phenolic compounds (Yigit et al., 2001; Paudel et al., 2011; Theodora et al., 2013).

In developing countries, oil extraction from nonconventional sources should be encouraged to produce low-priced vegetable oil for consumers (Chatepa et al., 2019). Presently the wild olive has no proper use due to the lack of research on its compositional characteristics of oil or medicinal value of its parts (fruit and leaves) as has been reported in cultivated olive tree. Fruit of wild olive having rich oil content and leaves with nutritional as well as polyphenolic contents may be used as natural medicinal source, cheap renewable and rich source of antioxidants as well as for the fulfilment of oil requirement in developing countries like Azad Jammu and Kashmir and Pakistan. Research on its oil content and other phenolic compounds is the higher need of the day. Therefore, keeping in view the importance of wild olive, this experiment was performed to analyse chemical characteristics of this plant in order to explore nutritional as well as medicinal value of its parts (fruit and leaves) and quality of its oil to make it more helpful and beneficial for the community.

\section{Materials and Methods}

The present experiment was conducted in the research laboratory of the Department of Food Science and Technology, University of the Poonch Rawalakot, Azad Kashmir.

\section{Collection of plant material}

Sound and healthy samples (fruit and leaves) of wild olive (Olea cuspidata) were collected randomly from different trees of pearl valley of Rawalakot, Azad Kashmir in autumn season (October and November). Rawalakot lies in the north-east of Pakistan under foothills of great Himalayas in the Poonch Division. Rawalakot is located at Latitude 3351'32.18”N, Longitude 73 45’34.93”E and an Elevation of 5374 feet. It is characterized by moderate climate with annual rainfall between 500$2000 \mathrm{~mm}$. These collected samples were brought to the laboratory of Food Science and Technology, The University of Poonch Rawalakot, Azad Jammu and Kashmir.

\section{Making of fruit and leaves samples for proximate analysis} Fresh fruit collected from different locations were mixed and leaves samples were also mixed, air dried in shade separately. After drying these samples were ground into powder by using clean, dry pestle and mortar. These samples were then analyzed for moisture, crude fiber, crude protein, ash contents and total oil by AOAC (2000) method 925.09, method 962.09, method 920.15, method 940.26, method 920.39, respectively and nitrogen free extract (NFE) was estimated through following formula.

\section{NFE (\%) $=100-($ Crude protein + Crude fiber + Crude fat/oil + Total ash)}

The remaining samples of fruit and leaves were then separately stored in air tight containers until further use.

\section{Preparation of fruit and leaves extracts}

For the determination of total polyphenols and flavonoid contents, the fruit and leaves samples were extracted by the technique of solvent extraction. For this reason, 25 grams of the fruit and leaves samples 
(powdered) were taken in $500 \mathrm{ml}$ conical flasks and separately extracted with methanol (80\%), ethanol (80 $\%)$, acetone (80 \%) and $100 \mathrm{ml}$ of deionised distilled water. After plugging with rubber corks these conical flasks were shaken by shaker ( $120 \mathrm{rpm}$ for 30 minutes) and kept for a period of 5 days at room temperature. During this period, these flasks were agitated after every 24 hours by using sterile glass rod. After 5 days, these extract samples were separately filtered using sterile filter paper. The resulting filtrate was then dried in a rotary evaporator. Dried extract was stored in labelled sterile screw capped bottles at $4^{\circ} \mathrm{C}$.

\section{Determination of total phenolic and total flavonoid} content

Total phenolic content (TPC) of fruit and leaves of wild olive was assayed in triplicate by the method of Folin- Ciocalteu (Nasri et al., 2011) and total flavonoid content (TFC) of fruit and leaves of wild olive was examined according to the method adapted by Rigane et al. (2012).

\section{Physicochemical analysis of wild olive oil}

The physicochemical characteristics of oil like refractive index, specific gravity, $\mathrm{pH}$, color, free fatty acid, peroxide, iodine value, saponification number and unsaponifiable matter were identified. The color was observed by visual examination, while $\mathrm{pH}$ was estimated by using $\mathrm{pH}$ meter. The specific gravity, refractive index, peroxide, iodine value and saponification number were determined according to methods of AOAC (2000). Free fatty acid was determined by AOCS (1990). The unsaponifiable matter was identified by the procedure defined by Bastic et al. (1978).

\section{Statistical analysis}

Values shown in the tables are the means and standard deviations for three replicates.

\section{Results and Discussion}

\section{Chemical analysis of wild olive fruit and leaves}

Results concerning chemical composition (moisture content, fibre, crude protein, total oil, ash contents and nitrogen free extract) of Olea cuspidata fruit and leaves are presented in Table 1 . These outcomes indicated a variation between composition of fruit and leaves extracts and it was observed that the leaves had comparatively higher moisture $(53.33 \pm 1.4 \%)$, protein $(8.20 \pm 0.80 \%)$, ash $(5.33 \pm 0.8 \%)$, crude fibre
$(10.0 \pm 0.9 \%)$ and nitrogen free extract as compared to fruit having comparatively lower $(48.33 \pm 1.6$, $0.80 \pm 0.02 \%, \quad 1.71 \pm 0.2 \%, \quad 4.40 \pm 0.3 \%, \quad 10.47 \pm 1.9$ $\%, 72.10 \pm 0.5$ and $16.02 \pm 0.1)$ contents of these constituents, respectively. The percentage of crude fat/oil $(34.43 \pm 1.1 \%)$ was higher in fruit samples as compared to leaves having very lower $(1.00 \pm 0.6$ $\%)$ content of oil. These results coincide with those reported by Gulfraz et al. (2009) who observed variation in composition of wild olive fruit with respect to these constituents like moisture content (42-60\%), protein (0.5-1.1\%), oil (32.1-38.6), fibre (2.6-6.5 \%) and ash (1.7-2.1\%). Tanjour (2013) also observed the variation in moisture (39.1-58.6\%) and ash content (0.7-1.1\%) of fruit sample. Similarly, Lafka et al. (2013) observed lower moisture (50.5 $\%)$, fat/oil (1.2\%) and higher ash content (3.7 \%) in leaves, which is in agreement with our study. The lower values of protein and higher values of total oil in fruit validated suitability of this oil for edible purposes like cultivated olive oil. Table 2 showed that higher total phenolic content (TPC) both in fruit and leaves was observed in methanol $(80.10 \pm 1.5 \mathrm{mgGAE} / \mathrm{g}$ and $112.35 \pm 1.9 \mathrm{mgGAE} / \mathrm{g}$ ) followed by ethanol $(74.20 \pm 1.2 \mathrm{mgGAE} / \mathrm{g}$ and $103.32 \pm 108 \mathrm{mgGAE} / \mathrm{g})$, acetone $(69.11 \pm 1 \mathrm{mgGAE} / \mathrm{g}$ and $95.20 \pm 1.5$ $\mathrm{mgGAE} / \mathrm{g})$ and water $(65.00 \mathrm{mgGAE} / \mathrm{g} \pm 0.8$ and $84.29 \pm 1.4 \mathrm{mgGAE} / \mathrm{g}$ ), respectively with average means of $96.22 \mathrm{mgGAE} / \mathrm{g}, 88.76 \mathrm{mgGAE} / \mathrm{g}, 82.15$ $\mathrm{mgGAE} / \mathrm{g}, 74.64 \mathrm{mgGAE} / \mathrm{g}$ with response to these solvents. Methanol was proved to be more effective solvent and water was least effective. This might be due to many bioactive compounds exhibit hydrophobic properties, which leads to their limited solubility in water. Among organic solvents, methanol was most effective followed by ethanol and acetone. This might be due to difference in their polarities (as methanol is more polar than other alcohols) which influenced the solubility of phenolic contents as described by Zhou and Yu (2004) or due to the selective solubility of phytochemicals in a given solvent as reported by Medini et al. (2014). Our results are in line with those of Nashwa and Abdel-Aziz (2014) and Rimavi and Salim (2016) who observed the similar results by studying solvents. More phenolic content was observed in leaves than fruit which might be due to difference in morphological parts of plant that were developed under variable environmental factors. Our results are in accordance with those of Xie et al. (2015) who described more amount of TPC in extract of olive leaves than in fruit extract. Table 3 showed a 
significant difference of TFC among different solvents and a higher TFC in fruit and leaves $(21.30 \pm 0.9 \mathrm{mg} / \mathrm{g}$ and $39.00 \pm 1.0 \mathrm{mg} / \mathrm{g}$ ) was observed in methanol, followed by ethanol $(17.10 \pm 0.4 \mathrm{mg} / \mathrm{g}$ and $33.20 \pm 0.9$ $\mathrm{mg} / \mathrm{g})$, acetone $(14.30 \pm 0.5 \mathrm{mg} / \mathrm{g}$ and $28.10 \pm 1.2 \mathrm{mg} / \mathrm{g})$ and water $(11.40 \pm 0.7 \mathrm{mg} / \mathrm{g}$ and $23.30 \pm 0.7 \mathrm{mg} / \mathrm{g}$ ), respectively with their significantly different average means of $30.15 \mathrm{mg} / \mathrm{g}, 25.15 \mathrm{mg} / \mathrm{g}, 21.20 \mathrm{mg} / \mathrm{g}$ and $17.35 \mathrm{mg} / \mathrm{g}$. The dissimilarity of TFC in different solvents might be due to different polarities of solvents which played a key role in increasing polyphenolic solubility and highly methoxylated flavonols tend to be more soluble in non-aqueous solvents which is in agreement with Escribano and Buelga (2003). More flavonoid content was observed in leaves than in fruit extract which is in line with Xie et al. (2015) who noticed that TFC was more in extract of olive leaves than in olive fruit extract. Table 4 showed the results of physicochemical characteristics of oil like the colour of $O$. cuspidata fruit was yellow, refractive index $(1.3 \pm 0.1)$, specific gravity $(0.93 \pm 0.02), \mathrm{pH}$ values $(5.4 \pm 0.2)$, free fatty acid value $(0.7 \pm 0.03 \%)$, peroxide value $(8.50 \pm 0.4 \mathrm{mg} / \mathrm{kg})$, iodine value $(79.99 \pm 0.58$ $\mathrm{mg} / 100 \mathrm{~g})$, saponification number $(180.00 \pm 0.91 \mathrm{mg} /$ $\mathrm{KOH} / \mathrm{g})$ and unsaponifiable matter $(1.40 \pm 0.5 \mathrm{~g} / \mathrm{kg})$ of wild olive oil. Our findings are correlated with those reported by Gulfraz et al. (2009) who observed nearly the same range of these characteristics in wild olive oil. Tanjour (2013) also reported almost the same values of free fatty acids $(0.87 \%)$ and saponification number $(192 \mathrm{mg} / \mathrm{KOH} / \mathrm{g})$ in wild olive oil which correspond to our findings. Our study indicated that the level of free fatty acids was very low in the wild olive oil which is a sign of its good quality and might be stored for a long time without spoilage through oxidative rancidity. The peroxide value of wild olive oil was also comparable to commercially available oil and specifies its suitability for edible purposes as was shown by other scientists like Gulfraz et al. (2009). In our study the free fatty acid, peroxide value and refractive index of wild olive oil was in range of other scientists like Abdalla et al. (2014) who described previously in cultivated edible olive oil. The wild olive having saponification number, iodine value and the unsaponifiable value of olive oil is also within the range of edible olive oil as reported by Muço et al. (2015). In our study all values of wild olive oil are almost comparable to commercially available cultivated olive oil and therefore after toxicological studies, we can use the wild olive not only for edible oil purpose to increase the economy of the area but its leaves which are rich source of nutrients and polyphenolic compounds may also be utilized for the improvement of human health by curing different chronic diseases.

Table 1: Composition of wild olive fruit and leaves samples.

$\begin{array}{lll}\text { Parameters (\%) } & \begin{array}{l}\text { Olea cuspidate } \\ \text { Fruit }\end{array} & \begin{array}{l}\text { Olea cuspidata } \\ \text { Leaves }\end{array} \\ \text { Moisture } & 48.33 \pm 1.6 & 53.33 \pm 1.4 \\ \text { Crude fiber } & 4.40 \pm 0.3 & 10.0 \pm 0.9 \\ \text { Crude Protein } & 0.80 \pm 0.02 & 8.20 \pm 0.80 \\ \text { Total oil } & 34.43 \pm 1.1 & 1.00 \pm 0.6 \\ \text { Ash contents } & 1.71 \pm 0.2 & 5.33 \pm 0.8 \\ \text { Nitrogen free extract } & 10.47 \pm 1.9 & 22.14 \pm 2.2\end{array}$

Table 2: Total phenolic content ( $m g G A E / g$ ) of fruit and leaves extract of Olea cuspidata samples collected from Rawlakot Azad Kashmir.

\begin{tabular}{llll} 
Treatments & \multicolumn{2}{c}{ Samples } & Mean \\
& Fruit & Leaves & \\
Ethanol & $74.20 \pm 1.2 \mathrm{f}$ & $103.32 \pm 1.8 \mathrm{~b}$ & $88.76 \mathrm{~B}$ \\
Methanol & $80.10 \pm 1.5 \mathrm{e}$ & $112.35 \pm 1.9 \mathrm{a}$ & $96.22 \mathrm{~A}$ \\
Acetone & $69.11 \pm 1 \mathrm{~g}$ & $95.20 \pm 1.5 \mathrm{c}$ & $82.15 \mathrm{C}$ \\
Water & $65.00 \pm 0.8 \mathrm{~h}$ & $84.29 \pm 1.4 \mathrm{~d}$ & $74.64 \mathrm{D}$ \\
Mean & $72.10 \mathrm{~B}$ & $98.79 \mathrm{~A}$ &
\end{tabular}

Table 3: Total flavonoid content ( $m g / g$ ) of fruit and leaves of Olea cuspidate samples collected from Rawlakot, Azad Kashmir.

$\begin{array}{llll}\text { Treatments } & \text { Samples } & & \text { Mean } \\ & \text { Fruit } & \text { Leaves } & \\ \text { Ethanol } & 17.10 \pm 0.4 \mathrm{e} & 33.20 \pm 0.9 \mathrm{~b} & 25.15 \mathrm{~B} \\ \text { Methanol } & 21.30 \pm 0.9 \mathrm{~d} & 39.00 \pm 1.0 \mathrm{a} & 30.15 \mathrm{~A} \\ \text { Acetone } & 14.30 \pm 0.5 \mathrm{f} & 28.10 \pm 1.2 \mathrm{c} & 21.20 \mathrm{C} \\ \text { Water } & 11.40 \pm 0.7 \mathrm{~g} & 23.30 \pm 0.7 \mathrm{~d} & 17.35 \mathrm{D} \\ \text { Mean } & 16.02 \mathrm{~B} & 30.90 \mathrm{~A} & \end{array}$

Table 4: Physicochemical characteristics of wild olive oil.

$\begin{array}{ll}\text { Color } & \text { Yellow } \\ \text { Refractive index } & 1.3 \pm 0.1 \\ \text { Specific gravity } & 0.93 \pm 0.02 \\ \mathrm{pH} & 5.4 \pm 0.2 \\ \text { Free fatty acids }(\%) & 0.7 \pm 0.03 \\ \text { Peroxide value }(\mathrm{mg} / \mathrm{kg}) & 8.50 \pm 0.4 \\ \text { Iodine value }(\mathrm{mg} / 100 \mathrm{~g}) & 79.99 \pm 0.58 \\ \text { Saponification number }(\mathrm{mg} / \mathrm{KOH} / \mathrm{g}) & 180.00 \pm 0.91 \\ \text { Unsaponificable matter }(\mathrm{g} / \mathrm{kg}) & 1.40 \pm 0.5\end{array}$

December 2020 | Volume 36 | Issue 4 | Page 1091 


\section{Conclusions and Recommendations}

Our study showed that parts of wild olive (fruit and leaves) are very important from nutritional and medicinal point of view. Among water and other organic solvents (methanol, ethanol and acetone) methanol showed more phenolic and flavonoid compounds in fruit and leaves of olive. Leaves showed more beneficial properties than fruit extracts due to higher content of polyphenolic compounds. Physicochemical properties of wild olive oil were almost comparable to commercially available cultivated olive oil and it can be used for edible purpose after toxicological studies.

\section{Novelty Statement}

Wild olive is endemic to Azad Kashmir and hilly areas of Pakistan. Keeping in view the importance of olive, this study explores the chemical constituents of fruit, leaves and oil of wild olive.

\section{Author's Contribution}

RR did the research work, analysed data and wrote paper. HAR gave the idea of research and designed the whole plan of study and gave guideline in this regard. TM collaborated in research and provided research facilities. IH provided guideline in paper writing and checking. IH provided guideline in study. All authors read and approved the final manuscript.

\section{Conflict of interest}

The authors have declared no conflict of interest.

\section{References}

Abdalla, I.H., M. Khaddor, A. Boussab, D. E1Garrouj and B. Souhial. 2014. Physical and chemical characteristics of olive oils from cooperatives for olive growers in the north of Morocco. Int. J. Bus. Appl. Sci., 14(2): 4-11.

AOAC, 2000. Official methods of analysis, association of official analytical chemists. $17^{\text {th }}$ Ed. Washington, D. C.

AOCS, 1990. Official methods and recommended practices, Vol. 1 (4t ${ }^{\mathrm{h}}$ ed). American oil chermists society, champaign, II.

Bartolini, G. and R.Petruccelli.2002.Classification, origin, diffusion and history of the olive. Plant production and protection, Div, FAO, Rome
(Italy).pp. 85.

Bastic, M., L. Bastic, J.A. Jabanovic and G. Spiteller. 1978. Hydrocarbons and other weakly unsaponifiables in some vegetable oils. J. Am. Oil Chem. Soc., 55: 886-892. https://doi. org/10.1007/BF02671413

Besnard, G., P.S. Greene and A. Serville. 2002. The genus Olea: molecular approaches of its structure and relationships to other Oleaceae. Acta Bot. Gallica., 149(1): 49-66. https://doi.or $\mathrm{g} / 10.1080 / 12538078.2002 .10515928$

Chatepa, L.E.C., H. Uluko and K. Masamba. 2019. Comparison of oil quality extracted from selected conventional and non-conventional sources of vegetable oil from Malawi. Afr. J. Biotechnol., 18(1): 171-180. https://doi. org/10.5897/AJB2018.16732

Escribano, M.T. and C. Santos-Buelga. 2003. Polyphenol extraction from foods. Methods Polyphenol. Anal. R. Soc. Chem. Reino Unido, pp. 1-16.

Ganino, T., G. Bartolini and A. Fabbri. 2006. The classification of olive germplasm. J. Hortic. Sci. Biotech., 81: 319-334. https://doi.org/10.1 080/14620316.2006.11512069

Gulfraz, M., R. Kasuar, G. Arshad, S.Mehmood, N. Minhas, M.J. Asad, A. Ahmad and F. Siddique. 2009. Isolation and characterization of edible oil from wild olive. Afr. J. Biotechnol., 8(16): 3734-3738.

Hannachi, H., W. Elfalleh and S. Marzouk. 2013. Oil, protein, antioxidants and free radical scavenging activity of stone from wild olive trees (Olea europaea L.). Pak. J. Pharm. Sci., 26(3): 503-510.

Hashmi, M.A., A. Khan, M Hanif, U. Farooq and S. Perveen. 2015. Traditional Uses, Phytochemistry, and Pharmacology of Olea europaea (Olive). J. Evid. Based. Complementary. Altern. Med., pp.1-29. https://doi.org/10.1155/2015/541591 Hegazi, E.S.S., A.A. Hegazi, M.M. Naguib and H.A. El-Attar. 2016. Anatomical study on the junction and location of abscission zone of olive fruit pedicels as affected by chemical loosening agents. J. Hortic. Sci. Ornamental Plants, 8(1): $19-25$.

Ivan, A.R., 2005. Medicinal plants of the world. Humana Press Inc, Totowa, New Jersey. pp. 623.

Karleskind, A. and J.P. Wolff. 1998. A comprehensive treatise properties-production-applications. Volume 1. Oils and fats manual, Paris 
Cedex 08.

Lafka, I.T., E.A. Lazou, J.V. Sinanoglou and E. Lazos. 2013. Phenolic extracts from wild olive leaves and their potential as edible oils antioxidants. Foods, 2(1): 18-31. https://doi. org/10.3390/foods2010018

Medini, F., H. Fellah, R. Ksouri and C. Abdelly. 2014. Total phenolic, flavonoid and tannin contents and antioxidant and antimicrobial activities of organic extracts of shoots of the plant Limonium delicatulum. J. Taibah Univ. Sci., 8: 216-224. https://doi.org/10.1016/j. jtusci.2014.01.003

Muço, M., A. Kopali and L. Muço. 2015. Physical and chemical characteristics of olive oils from autochthonous Albanian olive varieties. J. Hyg. Eng. Des. 12: 60-66.

Murkovic, M., S. Lechner, A. Pietzka, M. Bratocos and E. Katzogiannos. 2004. Analysis of minor components in olive oil. J. Biochem. Biophys. Methods, 61: 155-160. https://doi. org/10.1016/j.jbbm.2004.04.002

Nashwa, F.S.M. and M.E. Abdel-Aziz. 2014. Efficiency of olive (Olea europaea L.) leaf extract as antioxidant and anticancer agents. J. Agroaliment. Proc. Technol., 20(1): 46-53.

Nasri, N., N. Tlili, W. Elfallah, E. Cherif, A. Ferchichi, A. Khaldi and S. Triki. 2011. Chemical compounds from phoenician juniper berries (Juniperus phoenicea). Nat. Prod. Res., 18: 1733-1742. https://doi.org/10.1080/14786419 .2010 .523827

Nisar, A.S., A. Ahamd, M. Saleem and S.M. Khair. 2002. Constrains and opportunities in the Production and Marketing of wild olive in high land Balochistan: Farmers perception. Asian J. Plant Sci., 1: 370-372. https://doi.org/10.3923/ ajps.2002.370.372

Olivaria, S.A., M.B. Seabra and P.B. Andrade. 2005. Phenolic profiles of Portuguese olive fruits (Olea europaea L.): Influences of cultivar and geographical origin. Food Chem., 89: 561-568. https://doi.org/10.1016/j. foodchem.2004.03.012

Paudel, S., T. Magrati and J.R. Lamichhane. 2011. Antimicrobial activity of wild olive crude extracts in vitro. Int. J. Pharm. Sci. Res., 2(3): 110-113.

Rigane, G., M. Bouaziz, N. Baccar, S. Abidi, S.
Sayadi and R.B. Salem. 2012. Recovery of hydroxytyrosol rich extract from two-phase chemlali olive pomace by chemical treatment. J. Food. Sci., 77: 1077-1083. https://doi. org/10.1111/j.1750-3841.2012.02898.x

Rimavi, W.H. and H. Salim. 2016. Wild versus cultivated olive leaves extracts: Antioxidant activity, analysis of total phenolics and oleoropein content. J. Chem. Biochem., 4 (2): 61-88. https://doi.org/10.15640/jcb.v4n2a6

Sala-Vila, A., M. Guasch-Ferre, F.B. Hu, A. Sanchez-Tainta, M. Bullo, M. Serra-Mir and C. Lopez-Sabater. 2016. Dietary alpha-linolenic acid, marine omega- 3 fatty acids, and mortality in a population with high fish consumption: findings from the prevention con dieta mediterranea (PREDIMED) study. J. Am. Heart Assoc., 5(1). https://doi.org/10.1161/ JAHA.116.002077

Soni, M.G., G.A. Burdock, M.S. Christian, C.M. Bitler and R. Crea. 2006. Safety assessment of aqueous olive pulp extract as an antioxidant or antimicrobial agent in foods. Food Chem. Toxicol.,44:903-915.https://doi.org/10.1016/j. fct.2006.01.008

Tanjour,Z.,2014.An evaluation of physicochemical parameters of some wild olive oil varieties in Syrian Coastal Territor. J. Pharm. Phytother., 2(5): 146-153.

Theodora, I.L., L. Andriana, S. Vassilia and L. Evangelos. 2013. Phenolic extracts from wild olive leaves and their potential as edible oils antioxidants. Foods, 2: 18-31. https://doi. org/10.3390/foods2010018

Xie, P.J., C.H. Zhang, L.X. Huang and Y.L. Zhang. 2015. Phenolic compositions, and antioxidant performance of olive leaf and fruit (Olea europaea L.) extracts and their structureactivity relationships. J. Func. Foods, 16: 460471. https://doi.org/10.1016/j.jff.2015.05.005

Yigit, A.S., Y. Sahan and M. Korukluoglu. 2001. Antimicrobial substances found in olive leaves and olive. $2^{\text {nd }}$ Int. Altinouluk Antandros Olive Busines Symposium, Turkey. pp. 139-147.

Zhou, K. and L. Yu. 2004. Effects of extraction solvent on wheat bran antioxidant activity estimation. LWT- Food Sci. Technol., 37: 717721. https://doi.org/10.1016/j.lwt.2004.02.008 